\title{
Perceived Organizational ERP Benefits for SMEs: Middle Eastern Perspective
}

\author{
Soud Almahamid and Omer Awsi \\ Middle East University, Department of Business Administration, \\ Amman, Jordan
}

\author{
salmahamid@meu.edu.jo omer awsi@hotmail.com
}

\begin{abstract}
This study aims to examine the impact of organizational environment (top management support, company-wide support, business process reengineering, effective project management, and organizational culture) and enterprise resource planning (ERP) vendor environment (ERP vendor support) on ERP perceived benefits. In order to achieve the study's aim, a questionnaire was developed based on the extant literature to collect relevant data from the research informants. The population for this research consisted of all users of Microsoft Dynamics Great Plains (a typical type of enterprise system), which is frequently used in Jordanian companies in Amman City. A random sample of $30 \%$ of the research population was selected. The results revealed that business process reengineering, effective project management, company-wide support, and organizational culture have a positive correlation with ERP perceived benefits, whereas top management support does not. In addition, there is a significant positive correlation between vendor support and ERP perceived benefits. Academic and practical recommendations are provided.
\end{abstract}

Keywords: top management support, business process reengineering, effective project management, company-wide support, organizational culture, vendor support, SMEs, ERP benefits

\section{Introduction}

The unprecedented fundamental changes that have occurred in the business environment have made traditional business models, which focus on achieving the objectives of discrete functions, obsolete. In most cases, each functional unit works toward its own goals and objectives, rather than toward organizational goals. Hence, having a systematic view of information for all business activities becomes a challenge. Thus, it is necessary to develop integrated software that combines all functional data into one easily accessible database. The enterprise resource planning (ERP) system was invented to integrate business functions by consolidating functional data into one central database. Razmi, Sangari, and

Material published as part of this publication, either on-line or in print, is copyrighted by the Informing Science Institute. Permission to make digital or paper copy of part or all of these works for personal or classroom use is granted without fee provided that the copies are not made or distributed for profit or commercial advantage AND that copies 1) bear this notice in full and 2) give the full citation on the first page. It is permissible to abstract these works so long as credit is given. To copy in all other cases or to republish or to post on a server or to redistribute to lists requires specific permission and payment of a fee. Contact Publisher@,InformingScience.org to request redistribution permission.
Ghodsi (2009) defined ERP systems as "integrated and corporate-wide systems that automate core activities such as manufacturing, human resources, finance and supply chain management". In such systems the fragmented functional information is integrated to support the decision-making process and increase operational efficiency. A typical ERP system is composed of 14 mod-

Editor: Ewa Ziemba

Submitted: May 27, 2015; Revised August 17, September 11; 2015; Accepted: September 14, 2015 
ules: financials, controlling, plant maintenance, materials management, production planning, project management, sales and distribution, general logistics, quality management, human resources, supply chain management, customer relationship management, electronic-commerce, and advanced planner optimizer/advanced planner scheduler (Madapusi \& D'Souza, 2012). Thus, it is reasonable to expect that the more system modules that firms implement, the greater the benefits that can be derived from the system.

Prior research has mentioned some significant internal and external, tangible and intangible benefits of ERP implementation, including faster information sharing, greater financial management, reduced transportation and logistics costs, tighter supply chain relations, increased customer responsiveness, flexibility, productivity, and reduced inventory level (Dezdar \& Ainin, 2011b; Grabski, Leech, and Schmidt 2011; Patil, Narkhede, Mahajan, \& Joshi, 2012). However, in reality, it is difficult, if not impossible, to realize these benefits. This may be due to the methods and matrices used to evaluate ERP system success. According to Shao, Feng, and Liu (2012), the extant ERP literature has focused on assessing ERP success by whether the system is implemented on time and within budget, but has ignored the ultimate goal of the ERP system, which is to create business value and enhance business performance. The increasing number of ERP critical success factors (CSFs) studies around the globe supports Shao et al.'s assertion. CSFs are "the factors needed to ensure a successful ERP project" (Holland \& Light, 1999).

Until recently, researchers evaluated ERP systems from operational and managerial perspectives (Shao et al., 2012; Zhu, Wang, \& Chen, 2010), but ignored the strategic, IT infrastructure, and organizational benefits. In fact, there are a limited number of studies that focus on the operational, IT infrastructure, managerial, strategic, and organizational benefits of ERP, but what is missing in the literature is a clear link between the widely cited CSFs and the perceived benefits of ERP, especially at the post-implementation stage. Differences in language, culture, politics, government regulations, management styles, and labor skills determine the success of ERP and its perceived benefits (Sheu, Chae, \& Yang, 2004) and increase the failure rate of ERP, especially in developing countries such as Jordan (Hawari \& Heeks, 2010). This makes it worthwhile to understand how environmental factors such as organizational environment and vendor environment influence the expected benefits of ERP at the organization level. As Gable, Sedera, and Chan (2003) and Ifinedo (2011) noted, the most critical assessment factor for ERP success is organizational impact. Likewise, Zhang, Lee, Huang, Zhang, and Huang (2005) argued that only user satisfaction, intended business performance improvements, and predetermined corporate goals could be used as ERP success measures. However, predetermined corporate goals and business process improvements are two sides of the same coin. Therefore, we believe that evaluating ERP success requires a holistic approach that includes ERP operational, IT infrastructure, managerial, strategic, and organizational perceived benefits.

Accordingly, this study aims to examine and analyze the impact of organizational and vendor environment factors on the perceived benefits of ERP. This is because CSFs can vary not only from country to country but also from context to context within the same country. In addition, to the best of our knowledge, no study has investigated how CSFs influence ERP's perceived benefits, especially at the post-implementation phase. The rest of this paper is organized as follows. We begin by defining the research problem and the research objectives. These sections are followed by the literature review and a description of the development of the research model. The research method is then provided, and this is followed by an explanation of the research results. The research results are then summarized, and finally, a number of academic and practical recommendations are put forward. 


\section{Research Problem}

The dramatic, unprecedented, unforeseen, and unpredictable changes in the business environment today - changes in market demands, the development of new products, shortened lifecycle of the product development and production processes, changes in customers' needs and wants overnight, alteration of competitors' behaviors, government regulations, and technology's ubiquity together push companies to adopt the ERP system in order to consolidate the fragmented functional data that is distributed among legacy systems and to respond promptly and efficiently to these changes. In Jordan, most organizations now deploy the ERP system for two reasons: first, to overcome the issue of data transfer between legacy systems, or what is called the compatibility problem; and second, to improve their operational performance and deliver superior customer value. As a result, the positive impact seems to be the ultimate goal of ERP system implementation. However, many organizations fail to achieve this owing to a poor understanding of the complexity of the ERP system implementation lifecycle. Another reason of failure seems to be the gap between the assumptions/requirements of ERP and an organization's business process assumptions (Hawari \& Heeks, 2010).

Having the system running does not mean that its perceived benefits are achieved by default (Chou \& Chang, 2008; Nwankpa, 2015). As some anecdotal evidence indicates, the achievement of ERP's potential benefits is hardly present. Unsurprisingly, many ERP system implementations thus exceed their budget, fall behind schedule, and fail to attain their targeted expectations. In Jordan, these ERP implementation projects have encountered serious problems and are classified as complete failures. If large companies often struggle to realize ERP's perceived benefits, it will be even more difficult for (SMEs) to do so. Although the ERP literature highlights the importance of many CSFs in the ERP implementation success process, their importance is scarcely acknowledged in a different organizational context such as SMEs. In Jordan, despite the growing realization of the importance of SMEs market for many key ERP vendors, the relationship between CSFs and ERP perceived benefits is rarely addressed in SMEs in Jordan. Thus, it is worthwhile understanding the type of benefits SMEs usually experience in deploying the ERP system, and what factors are more likely to enhance its perceived benefits. Therefore, the research problem can be summarized by the following questions:

Q1: What are the key organizational environment factors that determine the perceived benefits of ERP for SMEs in Jordan?

Q2: What is the key vendor environment factor that determines the perceived benefits of ERP for SMEs in Jordan?

\section{Literature Review and Research Model}

In these sections we reviewed the extant literature of CSFs and perceived benefits of ERP to show the theoretical logic that underpin the formulation of each main and sub-hypotheses that are derived at the end of each section.

\section{CSFs and Perceived Benefits of ERP}

In order to avoid the costly failure of ERP system projects, researchers have identified many internal and external CSFs that play a role in the implementation process (Al-Masharim, AlMudimigh, \& Zairi, 2003; Finney \& Corbett, 2007; Ngai, Law, \& Wat, 2008; Wang, Shih, Jiang, \& Klein, 2008; Zhang et al., 2005; Zhu et al., 2010). Other researchers highlighted the positive impact of co-alignment among these factors on the success of ERP implementation (Wang et al., 2008). 
The number of CSFs is often very large and depends on the theoretical lens usually used by researchers to understand the ERP context (e.g., manufacturing or service sector) and on the research methods used (e.g., case study or questionnaire). The taxonomy of these factors differs not only from one country or region to another, but also within the country or the industry (Ngai et al., 2008). Thus, the inclusion of some CSFs and the exclusion of others in particular studies is still an extremely arbitrary and perplexing issue. However, it is reasonable to think that if a CSF has appeared frequently in many research studies, it is - at least theoretically - an influential determinant of an ERP system's post-implementation success (Gattiker \& Goodhue, 2005) and its perceived benefits. Some of the most often identified CSFs in prior studies include top management support, company-wide support, business process reengineering (BPR), effective project management, and organizational culture (Law \& Ngai, 2007; Ngai et al., 2008; Wang et al., 2008; Zhang et al., 2005; Zhu et al., 2010). Evidence in the literature has shown that there is a shortage of integrated models that handle the internal/external contextual factors as antecedents of ERP's success (Tsai et al., 2011) and its expected benefits.

Although organizations have continued to invest heavily in ERP, how to realize the maximum benefits and create superior business values remains a mystery (Nwankpa, 2015). Companies that have implemented ERP are expected to achieve various benefits from using the system. Previous literature classified ERP benefits into five categories: IT infrastructure, operational, managerial, strategic, and organizational benefits (Cheng \& Wang, 2006; Murphy \& Simon, 2002; Shang \& Seddon, 2000, 2002). Realizing the expected benefits of ERP usually takes 3-4 months (or more) after full deployment, but many organizations are still struggling to derive benefits from the ERP system they have implemented (Yu, 2005; Zhu et al., 2010). Ranganathan and Brown (2006) argued that ERP projects with "greater functional scope (two or more value-chain modules) or greater physical scope (multiple sites) result in positive, higher shareholder returns".

In their seminal theoretical work, Shang and Seddon (2002) classified ERP system benefits into IT infrastructure, operational, managerial, strategic, and organizational benefits. Cheng and Wang (2006) empirically showed how BPR influences the perceived benefits of ERP that were identified by Shang and Seddon (2002). Similarly, Zhu et al. (2010) applied Shang and Seddon's (2002) scale to measure the post-implementation success of ERP only from the operational and managerial benefits perspectives. Further, they argued that the ERP system directly affects the operational and managerial processes through improvements in those processes and can be better described as the direct advantages that ERP introduces to the organization, whereas the strategic and organizational benefits reflect the long-term gains of the organization, and it is hard to differentiate them from other factors such as market environment and business strategy in achieving competitive advantages for an organization. IT infrastructure benefits were excluded from the measures since the benefits from IT are not representative of the post-implementation success of ERP (Zhu et al., 2010). Likewise, Shao et al. (2012) focused on the ERP assimilation phase and measured the success of ERP from the improvement of operational and managerial benefits. However, the ERP system in both phases is used to execute real transactions (Zhu et al., 2010), and in turn, operational, managerial, and IT infrastructural benefits can be realized (Esteves, 2009; Kamhawi, 2008).

Other research explained how some CSFs may influence ERP's expected benefits. For example, Chou and Chang (2008) established that customization and organizational mechanisms foster immediate benefits from ERP (task efficiency and coordination improvements), which in turn increased ERP's overall performance. Nwankpa (2015) asserted that a precondition for immediate ERP system benefits is usage. At the same time, technical resources, organizational fit (which mainly reflects BPR activities), and the extent of ERP implementation are preconditions of effective ERP usage. To limit the scope of this study, we focus on six CSFs that are frequently identified as impacting on ERP post-implementation success (the phase where most of the perceived 
benefits of ERP can be achieved). The six CSFs can be classified under two broad contextual categories: organizational environment (the internal business environment) and vendor environment (the external business environment). These CSFs were chosen to provide an integrative view of the post-implementation organizational impact of ERP and include the main parties that determine ERP's implementation success and expected benefits (Wang et al., 2008). Thus, it is reasonable to hypothesize that there may be relationships between CSFs and the perceived benefits of ERP not only in the adoption/implementation process but also in the post-implementation process (Gattiker \& Goodhue, 2005), which is the focus of the current study. Based on the above discussion the following main hypotheses are proposed:

H01: There is no relationship between organizational environment and the perceived benefits of ERP.

H02: There is no relationship between vendor environment and the perceived benefits of ERP.

\section{Organizational Environment and Perceived Benefits}

Organizational environment is limited to five factors: top management support, company-wide

support, BPR, effective project management, and organizational culture (El Sawah, Abd El Fattah Tharwat, \& Hassan Rasmy, 2008; Zhang et al., 2005). These factors have been chosen because they are instrumental in determining the post-implementation success of ERP (Dezdar, 2010; Zhang et al., 2005). The following sections show how each organizational factor influences ERP's perceived benefits.

\section{Top management support}

Top management support is widely cited as one of the most influential CSFs that determine ERP implementation success (Dezdar \& Ainin, 2011a, 2011b, 2011c; Finney \& Corbett, 2007; Law \& Ngai, 2007; Nour \& Mouakket, 2011; Remus, 2007; Soja, 2006; Zhang et al., 2005). Top management can, among other roles, ensure ERP system approval and configuration, allocate the required resources, facilitate the learning process, secure high levels of coordination and control, remove hurdles and mitigate users' resistance, entice users to actively participate and use the system, direct a suitable implementation approach, and provide clear directions (Ngai et al., 2008; Wang et al., 2008; Yu, 2005; Zhang et al., 2005; Zhu et al., 2010).

Not surprisingly, $\mathrm{Yu}$ (2005) highlighted "CEO commitment and involvement" and "top- and middle-management commitment and involvement" as important root causes affecting the postimplementation effectiveness of ERP. Liang, Saraf, Hu, and Xue (2007) considered a model that enhances the diffusion and assimilation of ERP within organizations. Their model explains the role of top management in mediating the impacts of external institutional pressures on the effective use of ERP within organizations. More importantly, while Ngai et al. (2008) asserted that most, if not all, research studies in every region or country agreed that top management support is a prominent factor for successful implementation of ERP, Shao et al.(2012) confirmed the direct and indirect impact of transformational leadership on the success of ERP systems through knowledge sharing and organizational culture. Furthermore, Dezdar and Ainin (2011c) indicated that top management must provide full support and commitment for ERP projects in order for them to be successful. Chou and Chang (2008) suggested that top management support may influence the expected benefits of ERP. Therefore, if top management support is established, the perceived benefits of the ERP system will be ensured. Based on the above arguments, the following hypothesis can be set forth:

H01.1: There is no relationship between top management support and the perceived benefits of ERP. 


\section{Company-wide support}

Previous research has shown that company-wide support plays a vital role in ERP implementation success (Schniederjans \& Yadav, 2013; Yusuf, Gunasekaran, \& Abthorpe, 2004; Zhang et al., 2005). Since the implementation and maintenance of ERP is a complex phenomenon (Liang et al., 2007) aimed at integrating and consolidating data from various functional units, it is essential to obtain the total support of users from all functional units. Thus, the entire organization needs to provide full support in order to ensure that ERP implementation is successful (Moohebat, Jazi, \& Asemi, 2011). Several researchers have recognized the importance of company-wide support for the success of ERP implementation. For example, according to Zhang et al. (2005), "Every person and department is responsible/accountable for the overall system and key users from different departments are ensured to commit to the project implementation without being called back to their prior functional job position frequently."

Furthermore, Nah, Islam, and Tan (2007) argued that it is important for employees to be informed about the scope, objectives, activities, and updates in advance in order to make the ERP system more successful. Hawari and Heeks (2010) quoted from one of their interviews with ERP users in Jordan: "[T]here was no role for the users in the implementation process; they were placed on the sidelines watching what is happening." Others highlighted that the users had to adjust their daily working methods to fit the embedded business best practices in the ERP system (Maditinos, Chatzoudes, \& Tsairidis, 2011; Wang \& Chen, 2006). Thus, users' support, feelings of ownership, and positive attitudes toward the ERP system determined its use and ultimately its perceived benefits. Accordingly, a clear and honest explanation of the reasons for implementing ERP, the potential changes that may be required in current jobs and tasks, and the potential benefits for ERP users will ensure full support from the whole company. If company-wide support is established and well-activated, the perceived benefits of ERP will be achieved through the successful implementation of the project. Based on the above arguments, the following hypothesis can be asserted:

H01.2: There is no relationship between company-wide support and the perceived benefits of ERP.

\section{Business process reengineering}

BPR has been recognized as one of the key CSFs in the implementation success of ERP (Dezdar \& Ainin, 2011b; Law \& Ngai, 2007; Moohebat et al., 2011). BPR has been defined as a fundamental redesign of business processes to achieve dramatic improvements in critical performance areas such as cost, quality, service, and speed (Hammer, 1990). As ERP system implementation represents business best practices, a mismatch will exist between the structure of current business processes and that of the ERP system processes. This makes BPR necessary, and organizations must reengineer their business processes to achieve successful ERP implementation (Dezdar \& Ainin, 2011c; Yusuf et al., 2004) and gain some of ERP's perceived benefits.

However, when and how BPR impacts on the benefits of ERP implementation is, as yet, unknown and needs further clarification. Although Cheng and Wang (2006) assumed a cause and effect relationship between BPR processes and ERP benefits by examining relationships at the aggregate level, they offered no guidance on how BPR impacts each of the perceived benefits of ERP. In order to achieve large cost savings, improve operational efficiencies, and increase the speed and quality of production processes, organizations must implement high-quality BPR strategies. If organizations underestimate and fail to adapt current business processes to fit ERP system processes, the ERP project will be terminated (Zhang et al., 2005). According to Schniederjans and Yadav (2013), a greater understanding of user requirements defined by BPR and knowledge of users' needs is positively associated with the successful implementation of ERP. Therefore, im- 
plementing high-quality BPR enables organizations to reap many of ERP's perceived benefits. Based on the above arguments, the following hypothesis is proposed:

H01.3: There is no relationship between BPR and the perceived benefits of ERP.

\section{Effective project management}

Various studies have shown that effective project management is one of the CSFs of ERP implementation (Zhang et al., 2005; Zhu et al., 2010). As ERP implementation enables organizations to automate a large percentage of their routine jobs and standard operations, effective project management must take place in order to control the implementation process, prevent budget overrun, and ensure that implementation remains on schedule (Zhang et al., 2005).

Nowadays, the growing automation of many business processes and operations in organizations increases the need for data processing and reduces the number of human-related errors. Thus, the productivity of these business processes will be substantially improved, leading to several operational benefits (Zhu et al., 2010). Effective project management ensures that an ERP system will be implemented within the scheduled time and will be fully integrated with company-wide processes (Markus \& Tanis, 2000; Umble, Haft, \& Umble, 2003; Zhu et al., 2010). If effective project management is guaranteed, the ERP implementation process will not overrun in terms of time and budget, and the expected benefits of ERP will be ensured. Based on the above arguments, the following hypothesis is proposed:

H01.4: There is no relationship between effective project management and the perceived benefits of ERP.

\section{Organizational culture}

Several studies have highlighted the importance of organizational culture in the success of ERP implementation (Bharathi, Viadya , \& Parikh, 2012; El Sawah et al., 2008; Noudoostbeni, Ismail, Jenatabadi, \& Yasin, 2010; Zhang et al., 2005). However, they have often considered this as a postscript (Schniederjans \& Yadav, 2013). For example, Rugg and Krumbholz (1999) raised awareness of the need to minimize the cultural inertias that can prevent the better fit of ERP to an organization's context. Subsequently, Rugg et al. (2002) stressed the importance of correctly modeling the organizational culture before selecting and installing an ERP system. They described a model of culture that can be applied to the ERP context and described a framework for selecting an elicitation technique for modeling organizational culture.

Beliefs, attitudes, values, norms, and religious rules that are embedded in the national culture can influence organizational culture (Ngai et al., 2008) and ultimately the success of ERP implementation. Recent studies (El Sawah et al., 2008; Hawari \& Heeks, 2010) in the Middle East context show the relevance of organizational culture to ERP success. Middle Eastern culture has completely different beliefs, attitudes, values, norms, and religious practices from those in the Western culture, where ERP systems are often developed and implemented. Middle Eastern culture is characterized by a high level of uncertainty avoidance, high collectivism and power distance, and masculinity. As a result, Jordanian culture is unlike Western culture, and the entire community tends to be risk averse, to value relationship networks, to praise power, and to be reluctant to accept women's authority. Because ERP implementation brings various disruptions and uncertainty to current business processes, users avoid using it, react against it, and strive to retain their existing benefits.

When ERP values and assumptions about reality clash with the organizational culture, employees will resist using the ERP system, and this could ultimately lead to the failure of ERP. Another cultural factor of importance to ERP success is the level of collectivism, which is likely to hinder the functional coordination and integration that ERP aims to achieve (Zhang et al., 2005). Power 
distance is another cultural factor that may determine full functional usage of the ERP system. When employees accept and believe in power distance, they perceive that the implementation and use of ERP is the responsibility of top management rather than front-end employees, and this can lead to minimal ERP usage. With regard to the influence of masculinity on the success of ERP, although gender-specific behavior differences are crucial factors for system success and perceived benefits, the literature is still undecided, and rarely gives sufficient attention to this issue.

Prior literature emphasized the role of organizational culture as a determinant factor of the postimplementation success of ERP. For example, Jones, Cline, and Ryan (2006) suggested that organizational culture can impact knowledge sharing, which is a vital issue during the ERP implementation process. Organizational culture can significantly impact the ERP pre-implementation stage (Schniederjans \& Yadav, 2013). According to Ke and Wei (2008), ERP implementation success is positively related to organizational culture along the dimensions of learning and development, participative decision making, support and collaboration, and tolerance for risks and conflicts. In Jordan, Hawari and Heeks (2010) modeled culture by "objectives and values" in their design-reality gap model and argued that culture is the single most important reason for ERP failure. Organizational culture is often a reflection of the dominant national culture. National culture could be a source of human success or failure. Hence, the organizational culture of Jordanian SMEs is strongly affected by the national culture, and this could be a key determinant of the success and probabilistic benefits of the ERP system. Based on the above arguments, the following hypothesis is proposed:

H01.5: There is no relationship between organizational culture and the perceived benefits of ERP.

\section{ERP Vendor Environment and Perceived Benefits}

The vendor environment in this study is represented by one factor, namely vendor support. Vendor support is a prominent CFS for the implementation success of ERP and often includes streamlined business operations (Schniederjans \& Yadav, 2013), extended technical assistance, emergency maintenance, updates, service responsiveness, reliability, and user training (Ramayah, Roy, Arokiasamy, Zbib, \& Ahmed, 2007; Remus, 2007; Wang et al., 2008; Zhang et al., 2005), and mitigated ERP system determinants (Ifinedo, 2011). Since most, if not all, SMEs in Jordan purchase their ERP packages from Western ERP vendors and depend completely on outside consultancy services, it is essential to obtain vendor support.

The quality of vendor support plays a crucial role in shaping the success of ERP. According to Zhang et al. (2005), high-quality vendor support includes the following: (1) the service response time of the software vendor; (2) qualified consultants with knowledge of both the enterprise's business processes and IT, including vendors' ERP systems; and (3) participation of the vendor in ERP implementation. Nwankpa (2015) argued that vender support helps organizations that have implemented the ERP system to overcome knowledge gaps and uncertainties that usually accompany the implementation process. Other research has highlighted the importance of business employees' computer knowledge and in-house IT professionals' skills for ERP system effectiveness; however, SMEs rarely possess the required knowledge, and this lack of knowledge is likely to prevent knowledge flow from the ERP vendors (Ifinedo, 2011). In fact, SMEs are more in need of external professional domain knowledge than large companies (Ifinedo \& Nahar, 2006).

In the SME context, vendors provide higher-quality implementation services than do independent consultancies (Wang \& Chen, 2006). Thus, in order to develop a parsimonious model, it is essential that vendor and consultant support is combined. This is because there is convincing evidence that both types of support should be combined. For example, Sedera, Gable, and Chan (2003) found that "consultant and vendor items loaded together yielding a new factor named external 
knowledge player." Ifinedo (2011) combined vendor support and consultant support into one factor called external expertise. Hence, securing both types of support reduces the high rate of failure of ERP and boosts its expected benefits. Without continuous help from ERP vendors, ERP's projected benefits would not be forthcoming. Thus, the following hypothesis is proposed:

H02: There is no relationship between vendor environment (vendor support) and the perceived benefits of ERP.

\section{Research Model}

Drawing on the vast amount of ERP CSF literature and the comprehensive framework developed by Zhang et al. (2005), factors that impact the perceived benefits of ERP have been identified in this research. From Shang and Seddon's (2002) conclusive model the dependent variables that measure the perceived benefits of ERP are identified. The theoretical lens for this study includes Zhang et al.'s CSFs as the basis for independent variable identification, and Shang and Seddon's comprehensive framework of ERP perceived benefits as the basis for dependent variables identification that are relevant to the two environmental groups. While Zhang et al.'s combined CSFs were identified in previous studies as forming four environmental groups that determine ERP success (organizational environment, user environment, system environment, and ERP vendor environment), two of these groups (user environment and system environment) are not applicable to the ERP post-implementation context, as user environment includes factors related to user training and involvement, which are more appropriate for the ERP pre-implementation process than for post-implementation. The system environment is also not applicable to the ERP context because it includes factors related to system suitability, information quality, and system quality, and these are more relevant to the voluntary use of the ERP system rather than its compulsory use. In addition, system environment factors should be established during the BPR process rather than in the later phases. Shang and Seddon's (2002) comprehensive ERP model is widely accepted to measure the perceived benefits of ERP and as being suitable for measuring perceived benefits from different angles. The main focus of this study is to understand the impact of organizational and vendor environments on the perceived benefits of ERP. The research model is depicted in Figure 1. The model precisely delineates the research variables and the hypothesized relationships.

\section{Research Method}

\section{Sampling Frame and Data Collection}

This study examines the impact of organizational environment and vendor environment CSFs on the perceived benefits of ERP. The population of this study includes all users of Microsoft Dynamics Great Plains (one type of ERP) in SMEs in Jordan that have successfully implemented ERP. For the purpose of this research, small enterprises are defined as those with 50 employees or less while medium enterprises as those with 51 employees or more but fewer than 250 employees. As Jordan is almost identical to many developing countries, it has become a target for key ERP vendors looking for significant market growth and expansion (Hawari \& Heeks, 2010). Simultaneously, ERP implementation projects in Jordan have encountered severe problems and, in many cases, these projects can be classified as complete failures (Hawari \& Heeks, 2010). 


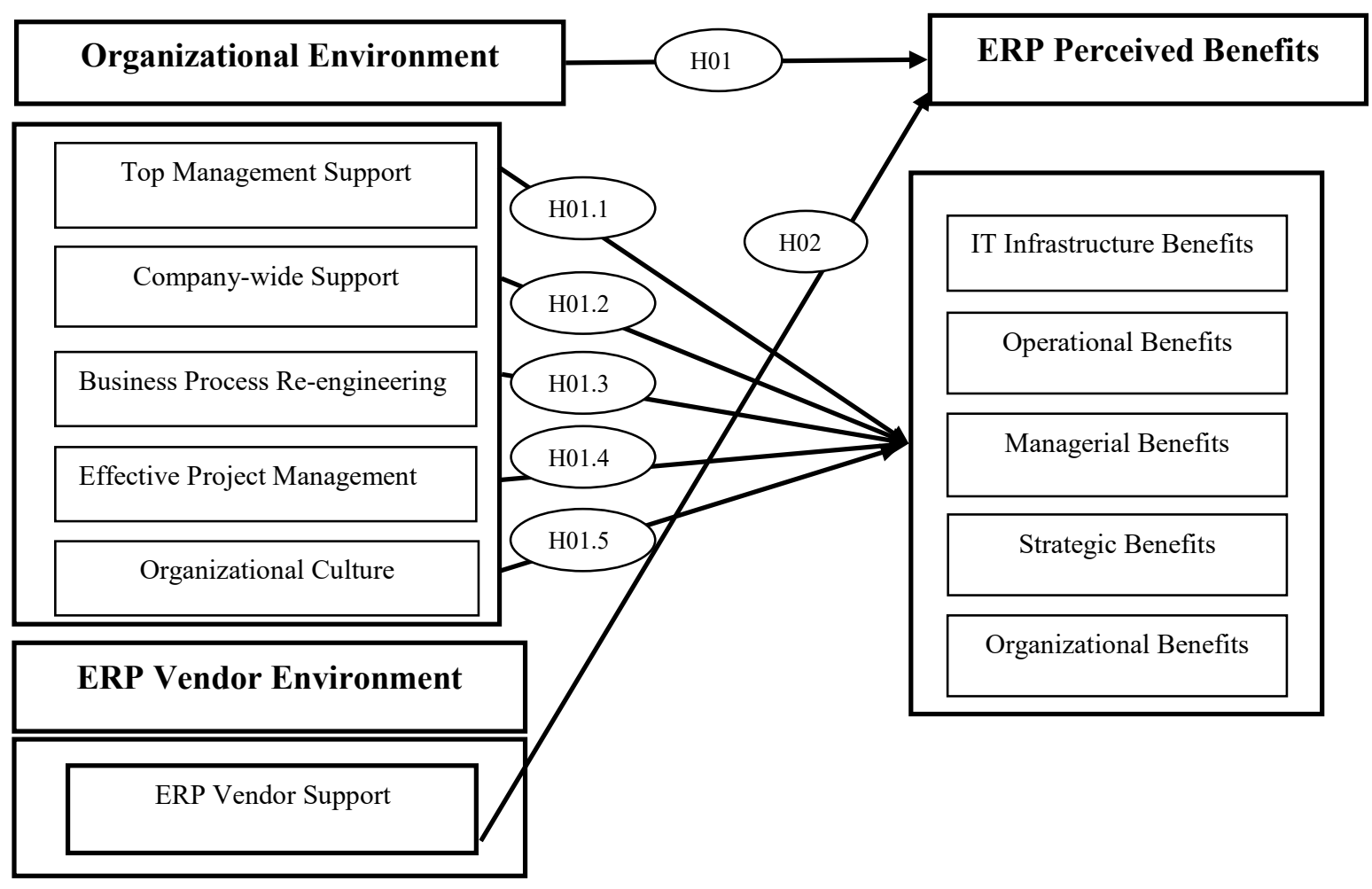

Figure 1: Research model

We focus on SMEs because they represent an attractive potential market for ERPs and the ERP literature for large organizations is saturated. A list of SMEs was obtained from a Microsoft Gold Partner located in Jordan that is a specialist in implementing and selling Microsoft business packages. The list contains 59 companies that have implemented ERP systems for more than a year. A preliminary request was sent to the target companies inviting them to participate in the study, with a brochure explaining the study's aims and objectives. Of the 59 companies contacted by the researchers, only 18 agreed to participate in the study. The IT manager in each company was designated the contact point and the person responsible for distributing the questionnaire to the most knowledgeable respondents. Each company agreed to fill in 10 questionnaires. Thus, the sample for this research is a random sample and represents $30 \%$ of the research population. One criterion was employed to select the target respondents, namely that they had been interacting with the ERP system for at least one year in order to do their job tasks. The questionnaire was sent to 180 end-users in those companies that had already implemented ERP systems and agreed to participate in the study. During the data collection period from March to June 2013, 180 questionnaires were distributed and 112 retrieved. Of the returned questionnaires, 11 responses were excluded owing to the large percentage of missing values and multiple answers to questions. Accordingly, only 101 responses were valid for data analysis.

\section{Measurements}

The study followed an approach suggested by Churchill (1979) in relation to scales development. First, the research constructs were operationally defined in order to measure them accurately and decide which dimensions should be included or excluded. Second, an extensive literature review was carried out in order to search for valid and reliable scales. Appropriate measures were adopted from the related literature where possible. The independent variables were organization envi- 
ronment and vendor environment. Organization environment includes five factors: top management support, company-wide support, BPR, effective project management, and organizational culture. Top management support refers to the degree to which top management has been involved in ERP implementation and has allocated the necessary resources to ensure successful ERP implementation. Top management support items were adopted from Wang et al. (2008), Zhu et al. (2010), and Dezdar and Ainin (2011a).

Company-wide supportrefers to the willingness of users to support the ERP project and accept the corresponding organizational changes required during the implementation lifecycle. Five items for measuring company-wide support were adopted from Wang and Chen (2006) and Maditinos et al. (2011). BPR refers to the fundamental redesign of current business processes to reap the perceived benefits of embedded ERP business best practices. The items for measuring BPR were adopted from Dezdar and Ainin (2011b). Effective project management refers to a well-managed ERP project that enables the implemented ERP system to realize the perceived benefits on time and within budget. Items that measure effective project management were adopted from Zhu et al. (2010) and Dezdar and Ainin (2011b). Organizational culture refers to the set of values, norms, attitudes, and behaviors that are conducive to change brought about by ERP system implementation. Cameron and Quinn's (2005) instrument was adopted to diagnose organizational culture, which contains 24 items. Vendor environment includes one factor: ERP vendor support. This refers to the continuous commitment of the ERP vendor toward the buyer organization in offering all types of support (training support, technical support, quality support, open communications) during the ERP project lifecycle. Vendor support items were adopted from Wang et al. (2008). Perceived benefits as a dependent variable is also considered a second-order construct and consists of IT infrastructure benefits, operational benefits, managerial benefits, strategic benefits, and organizational benefits (Shang \& Seddon, 2002; Shao et al., 2012; Zhang et al., 2005; Zhu et al., 2010).

IT infrastructure benefits are related to the benefits that result from putting the ERP system into full operation, thus increasing the capability to handle IT-related applications and tasks. Operational benefits are those brought about by introducing the ERP system into operational processes such as procurement, inventory management, and customer service. Managerial benefits are associated with the efficiency and effectiveness that the ERP system provides to managerial decisionmaking processes. Strategic benefits represent the competitive advantages brought by the ERP system, including in terms of business growth, innovation, and differentiation. Organizational benefits pertain to the improvements in an organization's learning and in how it carries out its strategy by utilizing the ERP system. All the items measuring the perceived benefits of ERP were adopted from studies by Shang and Seddon (2002), Zhang et al. (2005), Zhu et al. (2010), and Shao et al. (2012). The Appendix shows all the questionnaire items were measured using a fivepoint Likert scale with $1=$ strongly disagree and $5=$ strongly agree.

\section{Validity and Reliability}

In order to validate the data collection instrument used in this study in terms of its readability, format, and ability to measure the study's constructs, the questionnaire was distributed to a number of professors in public and private universities in Jordan who are experts in this field of study. The questionnaire instrument was then updated and refined to reflect the comments and suggestions received from the domain experts. The experts showed interest in and interacted effectively with the questionnaire items, which adds to its validity. In order to measure the internal consistency and reliability of the study's constructs, Cronbach's alpha $(\alpha)$ was used. The scales' reliabilities were measured and the Cronbach's alphas of all scales ranged from 0.775 to 0.941 (see Table 1), indicating a good level of reliability (Hair, Black, Babin, Anderson, \& Tatham, 2006). 
Table 1: Reliability Analysis for the Research Constructs

\begin{tabular}{|l|c|c|}
\hline \multicolumn{1}{|c|}{ Construct } & Items & Cronbach's alpha (a) \\
\hline Top Management Support & 2 & 0.811 \\
\hline Business Process Reengineering & 3 & 0.895 \\
\hline Effective Project Management & 4 & 0.883 \\
\hline Company-wide Support & 5 & 0.940 \\
\hline Organizational Culture & 24 & 0.782 \\
\hline Vendor Support & 3 & 0.875 \\
\hline IT Infrastructure Benefits & 3 & 0.901 \\
\hline Operational Benefits & 5 & 0.941 \\
\hline Managerial Benefits & 3 & 0.797 \\
\hline Strategic Benefits & 5 & 0.814 \\
\hline Organizational Benefits & 4 & 0.775 \\
\hline
\end{tabular}

A bivariate Pearson correlation test was conducted to ensure the independence of research variables. The correlation coefficient between each pair of independent variables should not be greater than 0.70 to ensure that each independent variable contributes in the regression equation and explains part of dependent variable variance. Based on the correlation values in Table 2, there are significant relationships between the research variables. However, these correlations are not sufficiently high for multicollinearity to be a concern. Therefore, the research variables are independent and none of the correlation coefficients between independent variables exceeds the accepted cutoff point. Hence, the data is ready and valid to be used for regression analyses. Table 2 presents the means and standard deviations, and the correlation matrix.

Table 2: Bivariate Pearson Correlation

\begin{tabular}{|l|c|c|c|c|c|c|c|c|c|c|c|c|c|}
\hline & MN & SD & TMS & BPR & EPM & CW & OC & VS & INF & OPR & MG & STR & ORG \\
\hline TMS & 3.9 & 0.74 & $\mathbf{1 . 0 0}$ & & & & & & & & & & \\
\hline BPR & 3.6 & 0.80 & 0.13 & $\mathbf{1 . 0 0}$ & & & & & & & & & \\
\hline EPM & 3.8 & 0.83 & $0.27^{* *}$ & $0.45^{* *}$ & $\mathbf{1 . 0 0}$ & & & & & & & & \\
\hline CW & 3.7 & 0.95 & 0.03 & $0.62^{* *}$ & $0.33^{* *}$ & $\mathbf{1 . 0 0}$ & & & & & & & \\
\hline OC & 3.8 & 0.89 & $0.27^{* *}$ & $0.58^{* *}$ & $0.63^{* *}$ & $0.61^{* *}$ & $\mathbf{1 . 0 0}$ & & & & & & \\
\hline VS & 3.7 & 0.99 & $0.45^{* *}$ & $0.32^{* *}$ & $0.53^{* *}$ & $0.21^{*}$ & $0.48^{* *}$ & $\mathbf{1 . 0 0}$ & & & & & \\
\hline INF & 3.6 & 1.00 & 0.02 & $0.64^{* *}$ & $0.39^{* *}$ & $0.74^{* *}$ & $0.68^{* *}$ & 0.15 & $\mathbf{1 . 0 0}$ & & & & \\
\hline OPR & 3.7 & 0.99 & 0.08 & $0.75^{* *}$ & $0.55^{* *}$ & $0.68^{* *}$ & $0.62^{* *}$ & $0.37^{* *}$ & $0.79^{* *}$ & $\mathbf{1 . 0 0}$ & & & \\
\hline MG & 3.5 & 0.88 & 0.13 & $0.57^{* *}$ & $0.41^{* *}$ & $0.62^{* *}$ & $0.50^{* *}$ & $0.24^{*}$ & $0.73^{* *}$ & $0.80^{* *}$ & $\mathbf{1 . 0 0}$ & & \\
\hline STR & 3.8 & 0.71 & 0.08 & $0.35^{* *}$ & $0.34^{* *}$ & $0.40^{* *}$ & $0.50^{* *}$ & 0.11 & $0.61^{* *}$ & $0.46^{* *}$ & $0.43^{* *}$ & $\mathbf{1 . 0 0}$ & \\
\hline ORG & 3.4 & 0.90 & $0.27^{* *}$ & $0.51^{* *}$ & $0.65^{* *}$ & $0.51^{* *}$ & $0.60^{* *}$ & $0.43^{* *}$ & $0.65^{* *}$ & $0.74^{* *}$ & $0.68^{* *}$ & $0.53^{* *}$ & $\mathbf{1 . 0 0}$ \\
\hline
\end{tabular}

** Correlation is significant at the 0.01 level (2-tailed); * Correlation is significant at the 0.05 level (2-tailed). $\mathrm{MN}$ : Mean; SD: standard deviation; TMS: top management support; BPR: business process reengineering; EPM: effective project management; CW: company-wide support; OC: organizational culture; VS: vendor support; INF: IT infrastructure benefits; OPR: operational benefits; MG: managerial benefits; STR: strategic Benefits; and ORG: organizational benefits. 


\section{Hypotheses Testing}

Since they meet the assumptions of regression analyses tests, the data can be subjected to further regression analyses. Simple regression analysis was used, as shown in Table 2, to test:

H01: There is no relationship between organizational environment and the perceived benefits of ERP.

Table 3: Simple Regression Analysis for H01

\begin{tabular}{|c|c|c|c|c|c|}
\hline $\mathbf{R}$ & Beta & $\mathbf{R}^{2}$ & ${\text { Adjusted } \mathbf{R}^{2}}^{2}$ & F Value & P Value \\
\hline $\mathbf{0 . 6 9 7}$ & $\mathbf{0 . 6 9 7 *}$ & $\mathbf{0 . 4 6 1}$ & $\mathbf{0 . 4 5 5}$ & $\mathbf{8 4 . 6 1 1}$ & $\mathbf{0 . 0 0 0 *}$ \\
\hline
\end{tabular}

Table 3 shows that the $F$ value is equal to 84.611 at significance level $p \leq 0.05$. This indicates that there is a relationship between the internal organizational environment and the perceived benefits of ERP. The beta value indicates that the impact of organizational environment on the perceived benefits of ERP is positive and equals $69.7 \%$. Based on the value of adjusted $\mathrm{R}^{2}$, organizational environment explains about $45.5 \%$ of the variance in the perceived benefits of ERP. However, it is important to understand how much each organizational factor explains the variance in perceived benefits. Thus, to test the impact of the dimensions of organizational environment altogether on the perceived benefits of ERP, multiple regression analysis was utilized. The results are shown in Table 4.

Table 4: Multiple Regression for Organizational Environment Dimensions and Perceived Benefits of ERP

\begin{tabular}{|l|c|c|c|c|c|}
\hline \multicolumn{1}{|c|}{$\mathbf{R}^{\mathbf{2}}$} & \multicolumn{2}{c|}{ Adjusted R $\mathbf{R}^{\mathbf{2}}$} & \multicolumn{2}{c|}{ F Value } & P Value \\
\hline \multicolumn{1}{|c|}{$\mathbf{0 . 6 5 0}$} & \multicolumn{2}{|c|}{$\mathbf{0 . 6 3 2}$} & \multicolumn{2}{c|}{$\mathbf{3 5 . 2 9 7}$} & $\mathbf{0 . 0 0 0 *}$ \\
\hline \multicolumn{1}{|c|}{ Constructs } & B Value & St. Error & Beta & T Value & P Value \\
\hline Top Management Support & 0.000 & 0.064 & 0.000 & -0.006 & 0.995 \\
\hline Business Process Reengineering & 0.229 & 0.075 & 0.253 & 3.052 & $0.003^{*}$ \\
\hline Effective Project Management & 0.164 & 0.074 & 0.178 & 2.219 & $0.029^{*}$ \\
\hline Company-Wide Support & 0.264 & 0.064 & 0.360 & 4.114 & $0.000^{*}$ \\
\hline Organizational Culture & 0.254 & 0.126 & 0.197 & 2.024 & $0.046^{*}$ \\
\hline
\end{tabular}

*Significant at $\mathrm{p} \leq 0.05$; dependent variable: ERP perceived benefits

Table 4 indicates that the dimensions of organizational environment (i.e., top management support, BPR, effective project management, company-wide support, and organizational culture) together explain about $63.2 \%$ of the variance in the perceived benefits of ERP on the basis of the adjusted $R^{2}$ value. The $F$ value is equal to 35.297 and thus significant at $p \leq 0.05$. This assures that there is a relationship between the dimensions of organizational environment and the perceived benefits of ERP. Moreover, and on the basis of the $t$ values, it can be seen that BPR, effective project management, company-wide support, and organizational culture have a positive impact on the perceived benefits of ERP at $p \leq 0.05$; meanwhile top management support has no significant impact on the perceived benefits of ERP at $\mathrm{p} \leq 0.05$. We also utilized stepwise multiple regression to determine the weight of importance of each dimension of organizational environment in the regression model in explaining the perceived benefits of ERP. As shown in Table 5, companywide support came first, explaining $48.0 \%$ of the variance in ERP perceived benefits. Effective project management was second in rank, and together with company-wide support explains about $58.1 \%$ of the variance in ERP perceived benefits. BPR was third, and with company-wide support and effective project management explains about $62.3 \%$ of the difference in ERP perceived benefits. Organizational culture was fourth, and with company-wide support, effective project management, and BPR explains about $63.5 \%$ of the variance in ERP perceived benefits. Top man- 
agement support was excluded from the regression analysis as it was not found to be significant in the previous multiple regression analysis, as shown in Table 5.

Table 5: Stepwise Multiple Regression for Organizational Environment Factors and ERP Perceived benefits

\begin{tabular}{|l|c|c|c|c|c|}
\hline $\begin{array}{c}\text { Order of Constructs in the Re- } \\
\text { gression Model }\end{array}$ & $\begin{array}{c}\text { Adjusted } \\
\mathbf{R}^{\mathbf{2}}\end{array}$ & F Value & $\begin{array}{c}\text { T } \\
\text { Value }\end{array}$ & Beta & $\begin{array}{c}\text { P } \\
\text { Value }\end{array}$ \\
\hline Company-Wide Support & 0.480 & 93.363 & 4.263 & 0.360 & $0.000^{*}$ \\
\hline Effective Project Management & 0.581 & 70.374 & 2.245 & 0.178 & $0.027^{*}$ \\
\hline Business Process Reengineering & 0.623 & 56.052 & 3.072 & 0.253 & $0.003^{*}$ \\
\hline Organizational Culture & 0.635 & 44.586 & 2.088 & 0.197 & $0.039^{*}$ \\
\hline
\end{tabular}

*Significant at $\mathrm{p} \leq 0.05$; dependent variable: ERP perceived benefits

After testing how organizational environment impacts the perceived benefits of ERP at the aggregate level, it is also important to test the relationship between each organizational environmental factor and each of the expected benefits of ERP.

H01.1: There is no relationship between top management support and the perceived benefits of ERP.

To test the first hypothesis, simple regression analysis was utilized, as shown in Table 6 .

Table 6: Simple Regression Analysis for H01.1

\begin{tabular}{|c|c|c|c|c|c|}
\hline $\mathbf{R}$ & Beta & $\mathbf{R}^{2}$ & Adjusted $\mathbf{R}^{2}$ & F Value & P Value \\
\hline $\mathbf{0 . 1 2 3}$ & $\mathbf{0 . 1 2 3}$ & $\mathbf{0 . 0 1 5}$ & $\mathbf{0 . 0 0 5}$ & $\mathbf{1 . 5 3 1}$ & $\mathbf{0 . 2 1 9}$ \\
\hline
\end{tabular}

Table 6 shows that the $F$ value is equal to 1.531 at significance level $p \leq 0.05$. This indicates that there is no significant relationship between top management support and the perceived benefits of ERP; thus, the null hypothesis is accepted. The beta value indicates that there is no significant impact of top management support on the perceived benefits of ERP. Further, we tested the impact of top management support on the dimensions of ERP perceived benefits using Smart PLS (PLS-SEM, partial least squares structural equation modeling), as shown in Figure 2. The path analysis is used for testing H0.1.1 to H01.5 and H02 for four reasons: PLS-SEM is often does not require any fit indexes; our focus is to test the research hypotheses on the individual level (the relationship between each CSF and each of ERP perceived benefits); the sample size is small; and the latent variable consists of several factors (Hair, Hult, Ringle, \& Sarstedt,, 2013). Therefore, we believe that the path analysis gives more reliable results than traditional regressions statistics in this case. Figure 2 shows that top management support has a significant positive impact only on organizational benefits $(t=3.811)$. The beta value, which indicates the strength of such an impact, is $34.0 \%$. On the basis of the $\mathrm{R}^{2}$ value, top management support explains $11.6 \%$ of the variance in organizational benefits. 


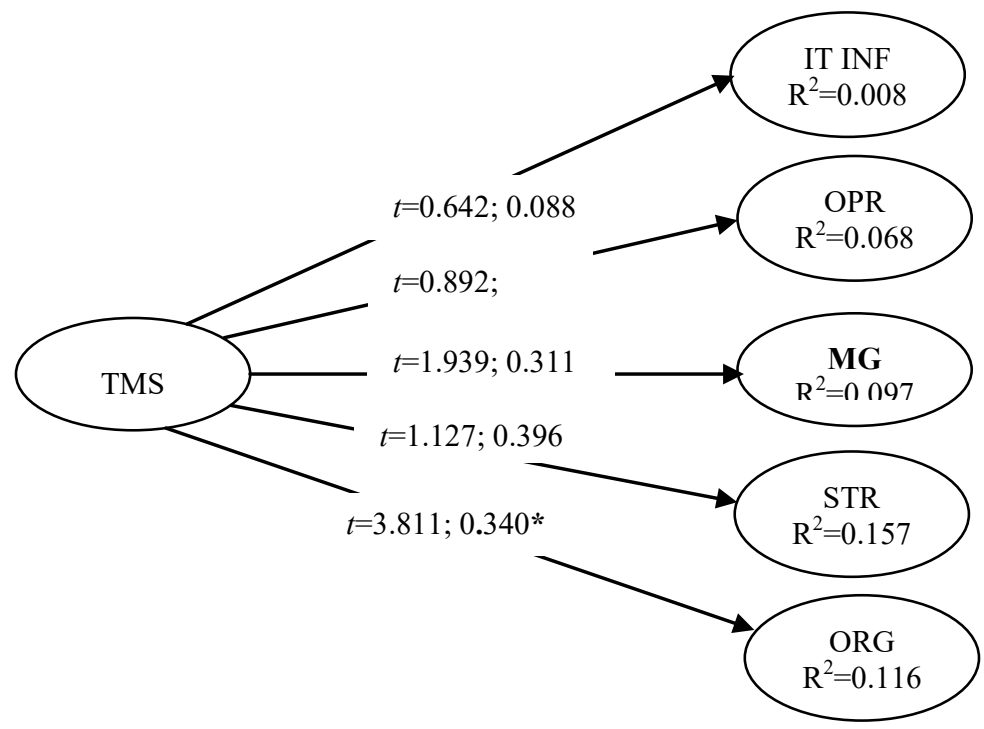

*Significant at $\mathrm{p} \leq 0.05$; TMS: top management support; INF: IT infrastructure benefits; OPR: operational benefits; MG: managerial benefits; STR: strategic benefits; and ORG: organizational benefits.

Figure 2: Path Analysis for H01.1

H01.2: There is no relationship between BPR and the perceived benefits of EPR.

To test the second hypothesis, simple regression analysis was utilized, as shown in Table 7.

Table 7: Simple Regression Analysis for H01.2

\begin{tabular}{|c|c|c|c|c|c|}
\hline $\mathbf{R}$ & Beta & $\mathbf{R}^{2}$ & Adjusted $\mathbf{R}^{2}$ & F Value & P Value \\
\hline $\mathbf{0 . 6 7 0}$ & $\mathbf{0 . 6 7 0} *$ & $\mathbf{0 . 4 4 9}$ & $\mathbf{0 . 4 4 4}$ & $\mathbf{8 0 . 7 3 0}$ & $\mathbf{0 . 0 0 0 *}$ \\
\hline
\end{tabular}

*Significant at $\mathrm{p} \leq 0.05$

Table 7 shows that the $F$ value is 80.730 at significance level $p \leq 0.05$. This indicates that there is a significant relationship between BPR and the perceived benefits of ERP; thus, the null hypothesis is rejected. The beta value indicates that there is a significant positive impact of BPR on the perceived benefits of EPR $67.0 \%$. Based on the value of adjusted $\mathrm{R}^{2}$, BPR explains about $44.4 \%$ of the variance in ERP perceived benefits. Further, we tested the impact of BPR on the dimensions of ERP perceived benefits using Smart PLS. As shown in Figure 3, and on the basis of $t$ values, BPR has significant positive impacts on all types of perceived benefits (i.e., IT infrastructure benefits, operational benefits, managerial benefits, strategic benefits, and organizational benefits). The beta values, which indicate the strength of such impacts, are also shown in Figure 3 . On the basis of the $\mathrm{R}^{2}$ value, BPR explains $41.8 \%, 56.7 \%, 36.6 \%, 13.9 \%$, and $34.2 \%$ of the variance in IT infrastructure benefits, operational benefits, managerial benefits, strategic benefits, and organizational benefits, respectively. 


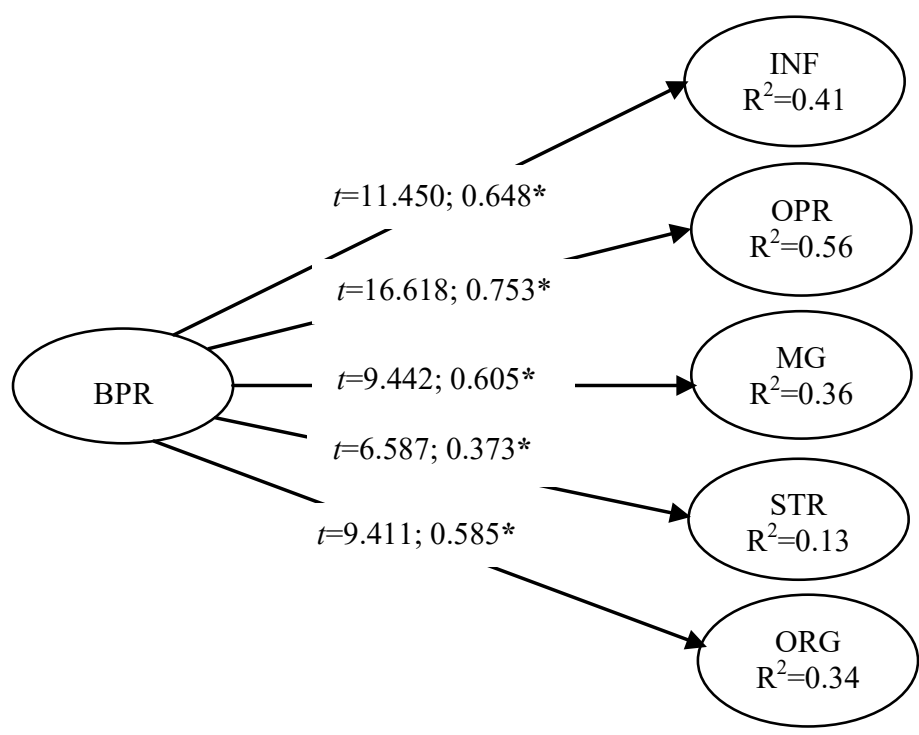

*Significant at $\mathrm{p} \leq 0.05$; BPR: business process reengineering; INF: IT infrastructure benefits; OPR: operational benefits; MG: managerial benefits; STR: strategic benefits; and ORG: organizational benefits.

Figure 3: Path Analysis for H01.2

H01.3: There is no relationship between effective project management and ERP perceived benefits.

To test the third hypothesis, simple regression analysis was utilized, as shown in Table 8.

Table 8: Simple Regression Analysis for H01.3

\begin{tabular}{|c|c|c|c|c|c|}
\hline $\mathbf{R}$ & Beta & $\mathbf{R}^{2}$ & Adjusted $\mathbf{R}^{2}$ & F Value & P Value \\
\hline $\mathbf{0 . 5 3 6}$ & $\mathbf{0 . 5 3 6 *}$ & $\mathbf{0 . 2 8 8}$ & $\mathbf{0 . 2 8 0}$ & $\mathbf{3 9 . 9 6 4}$ & $\mathbf{0 . 0 0 0 *}$ \\
\hline
\end{tabular}

*Significant at $\mathrm{p} \leq 0.05$

The $\mathrm{F}$ value is 39.964 at significance level $\mathrm{p} \leq 0.05$. This indicates that there is a significant relationship between effective project management and ERP perceived benefits; thus, the null hypothesis is rejected. The beta value indicates that there is a significant positive impact of effective project management on the perceived benefits of ERP (53.6\%). Based on the value of adjusted $\mathrm{R}^{2}$, effective project management explains about $28.0 \%$ of the variance in ERP perceived benefits. Further, we tested the impact of effective project management on the dimensions of ERP perceived benefits using Smart PLS. As shown in Figure 4, and on the basis of $t$ values, effective project management has significant positive impacts on all types of perceived benefits (i.e. IT infrastructure benefits, operational benefits, managerial benefits, strategic benefits, and organizational benefits). The beta values, which indicate the strength of such impacts, are also shown in Figure 4. On the basis of the $\mathrm{R}^{2}$ value, effective project management explains $16.3 \%, 35.3 \%$, $25.5 \%, 13.3 \%$, and $48.3 \%$ of the variance in IT infrastructure benefits, operational benefits, managerial benefits, strategic benefits, and organizational benefits, respectively. 


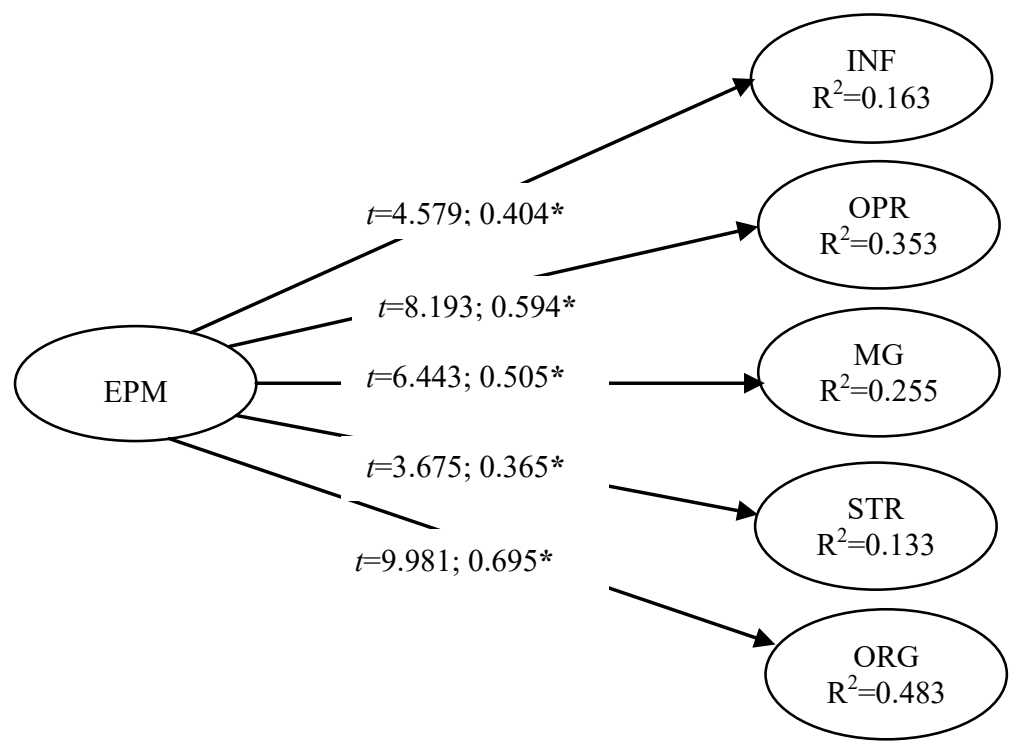

*Significant at $\mathrm{p} \leq 0.05$; EPM: effective project management; INF: IT infrastructure benefits; OPR: operational benefits; MG: managerial benefits; STR: strategic benefits; and ORG: organizational benefits.

Figure 4: Path Analysis for H01.3

H01.4: There is no relationship between company-wide support and the perceived benefits of ERP.

To test the fourth hypothesis, simple regression analysis was utilized, as shown in Table 9.

Table 9: Simple Regression Analysis for H01.4

\begin{tabular}{|c|c|c|c|c|c|}
\hline $\mathbf{R}$ & Beta & $\mathbf{R}^{2}$ & Adjusted $\mathbf{R}^{2}$ & F Value & P Value $^{2}$ \\
\hline $\mathbf{0 . 6 9 7}$ & $\mathbf{0 . 6 9 7 *}$ & $\mathbf{0 . 4 8 5}$ & $\mathbf{0 . 4 8 0}$ & $\mathbf{9 3 . 3 6 3}$ & $\mathbf{0 . 0 0 0 *}$ \\
\hline
\end{tabular}

*Significant at $\mathrm{p} \leq 0.05$

Table 9 shows that the $F$ value is 93.363 at significance level $p \leq 0.05$. This indicates that there is a significant relationship between company-wide support and ERP perceived benefits; thus, the null hypothesis is rejected. The beta value indicates that there is a significant positive impact of company-wide support on ERP perceived benefits (69.7\%). Based on the value of adjusted $\mathrm{R}^{2}$, company-wide support explains about $48.0 \%$ of the variance in ERP perceived benefits. Further, we tested the impact of company-wide support on the dimensions of ERP perceived benefits using Smart PLS. As shown in Figure 5, and on the basis of the $t$ values, company-wide support has significant positive impacts on all types of perceived benefits (i.e. IT infrastructure perceived benefits, operational perceived benefits, managerial perceived benefits, strategic perceived benefits, and organizational perceived benefits). The beta values indicating the strength of such impacts are also shown in Figure 5. On the basis of the $\mathrm{R}^{2}$ value, company-wide support explains $56.8 \%, 52.8 \%, 49.2 \%, 29.0 \%$, and $33.1 \%$ of the variance in IT infrastructure benefits, operational benefits, managerial benefits, strategic benefits, and organizational benefits, respectively. 


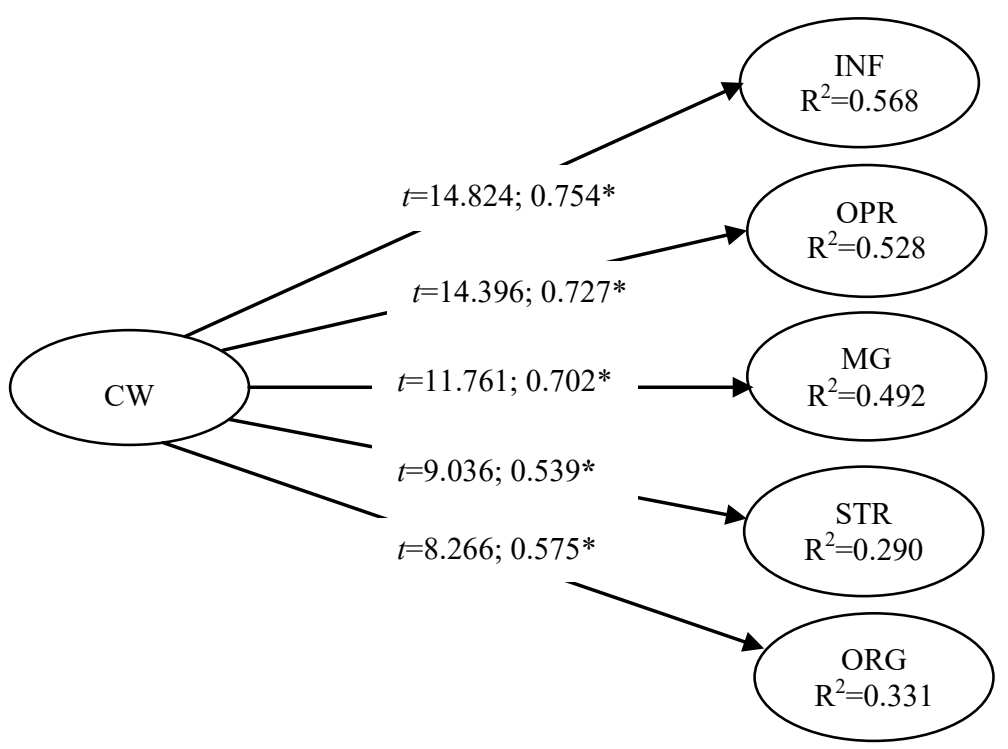

*Significant at $\mathrm{p} \leq 0.05$; CW: company-wide support; INF: IT infrastructure benefits; OPR: operational benefits; MG: managerial benefits; STR: strategic benefits; and ORG: organizational benefits.

Figure 5: Path Analysis for H01.4

H01.5: There is no relationship between organizational culture and the perceived benefits of ERP.

To test the fifth hypothesis, simple regression analysis was utilized, as shown in Table 10.

Table 10: Simple Regression Analysis for H01.5

\begin{tabular}{|c|c|c|c|c|c|}
\hline $\mathbf{R}$ & Beta & $\mathbf{R}^{2}$ & Adjusted $\mathbf{R}^{2}$ & F Value & P Value \\
\hline $\mathbf{0 . 6 7 8}$ & $\mathbf{0 . 6 7 8}^{*}$ & $\mathbf{0 . 4 5 9}$ & $\mathbf{0 . 4 5 4}$ & $\mathbf{8 4 . 0 4 2}$ & $\mathbf{0 . 0 0 0}^{*}$ \\
\hline
\end{tabular}

*Significant at $\mathrm{p} \leq 0.05$

Table 10 shows that the $F$ value is 84.042 at significance level $p \leq 0.05$. This indicates that there is a significant relationship between organizational culture and the perceived benefits of ERP; thus, the null hypothesis is rejected. The beta value indicates that there is a significant positive impact of organizational culture on ERP perceived benefits $(67.8 \%)$. Based on the value of adjusted $\mathrm{R}^{2}$, organizational culture explains about $45.4 \%$ of the variance in ERP perceived benefits. Further, we tested the impact of organizational culture on the dimensions of ERP perceived benefits using SmartPLS. As shown in Figure 6, and on the basis of $t$ values, organizational culture has significant positive impacts on all types of perceived benefits (i.e. IT infrastructure benefits, operational benefits, managerial benefits, strategic benefits, and organizational benefits). The beta values, which indicate the strength of such impacts, are also shown in Figure 6 . On the basis of the $\mathrm{R}^{2}$ value, organizational culture explains $57.6 \%, 72.8 \%, 44.7 \%, 36.1 \%$, and $57.9 \%$ of the variance in IT infrastructure benefits, operational benefits, managerial benefits, strategic benefits, and organizational benefits, respectively. 


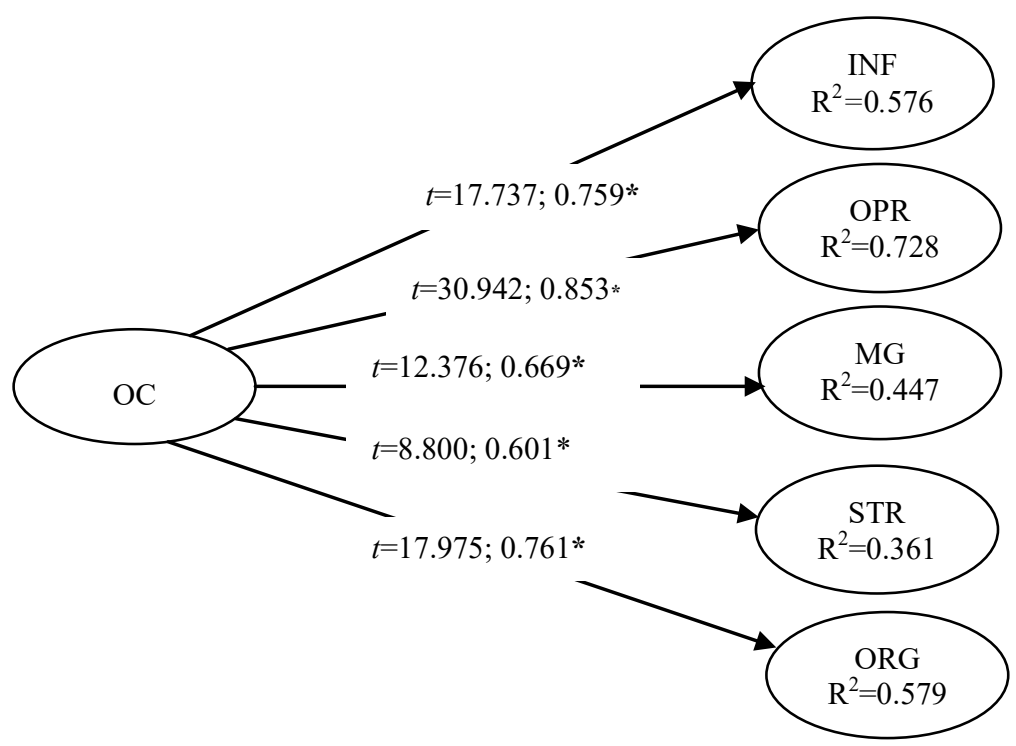

*Significant at $\mathrm{p} \leq 0.05$; OC: organizational culture; INF: IT infrastructure benefits; OPR: operational benefits; MG: managerial benefits; STR: strategic benefits; and ORG: organizational benefits.

Figure 6: Path Analysis for H01.5

H02: There is no relationship between vendor environment (vendor support) and the perceived benefits of ERP.

To test the sixth hypothesis, simple regression analysis was utilized, as shown in Table 11.

Table 11: Simple Regression Analysis for $\mathrm{HO2}$

\begin{tabular}{|c|c|c|c|c|c|}
\hline $\mathbf{R}$ & Beta & $\mathbf{R}^{2}$ & Adjusted $\mathbf{R}^{2}$ & F Value & P Value \\
\hline $\mathbf{0 . 2 9 6}$ & $\mathbf{0 . 2 9 6 *}$ & $\mathbf{0 . 0 8 7}$ & $\mathbf{0 . 0 7 8}$ & $\mathbf{9 . 4 8 0}$ & $\mathbf{0 . 0 0 3}^{*}$ \\
\hline
\end{tabular}

*Significant at $\mathrm{p} \leq 0.05$

Table 11 shows that the $F$ value is 9.480 at significance level $p \leq 0.05$. This indicates that there is a significant relationship between organizational environment represented by vendor support and the perceived benefits of ERP; thus, the null hypothesis is rejected. The beta value indicates that there is a significant positive impact of external organizational environment represented by vendor support on ERP perceived benefits (29.6\%). Based on the value of adjusted $\mathrm{R}^{2}$, external organizational environment represented by vendor support explains about $7.8 \%$ of the variance in ERP perceived benefits. Further, we tested the impact of vendor support on the dimensions of ERP perceived benefits using Smart PLS. As shown in Figure 7, and on the basis of $t$ values, vendor support has significant positive impacts on all types of perceived benefits (i.e. IT infrastructure benefits, operational benefits, managerial benefits, and organizational benefits), except strategic benefits. The beta values, which indicate the strength of such impacts, are also shown in Figure 7. On the basis of the $\mathrm{R}^{2}$ values, vendor support explains $6.2 \%, 21.6 \%, 12.0 \%$, and $29.0 \%$ of the variance in IT infrastructure benefits, operational benefits, managerial benefits, and organizational benefits, respectively. 


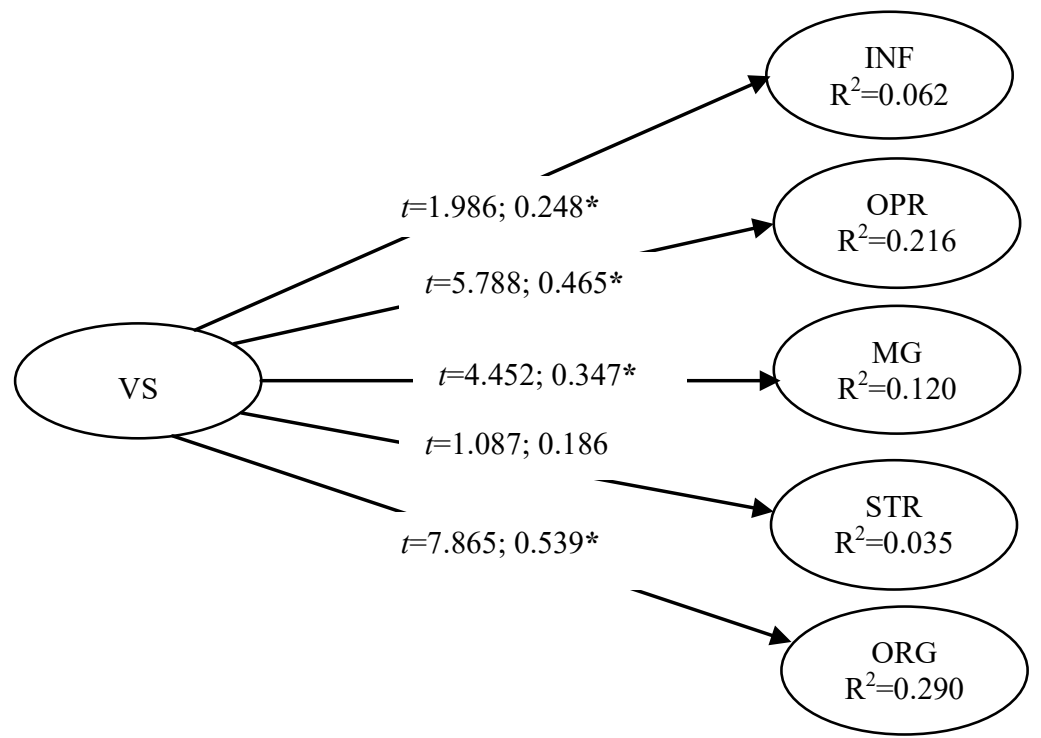

*Significant at $\mathrm{p} \leq 0.05$; VS: vendor support; INF: IT infrastructure benefits; OPR: operational benefits; MG: managerial benefits; STR: strategic benefits; and ORG: organizational benefits.

\section{Figure 7: Path Analysis for $\mathrm{HO2}$}

\section{Discussion}

The literature review on the CSFs of ERP and its perceived benefits revealed two main gaps. First, the majority of ERP CSFs literature was conducted in the developed countries. This is also pointed out by Ngai et al. (2008) and Dezdar and Ainin (2011a). Nevertheless, a few studies have focused on developing countries, including Jordan (Hawari \& Heeks, 2010). The current study, however, examines the relationship between top management support, company-wide support, BPR, effective project management, organizational culture, and ERP perceived benefits among ERP system end-users in Jordan. It goes far beyond the simple reporting of CSFs and illustrates how each CSF impacts the perceived benefits of ERP, identifying those that have the greatest impact.

The current study showed that organizational environment has a positive impact on the perceived benefits of ERP and explains about $45.5 \%$ of its variance. This result is in line with prior research (Zhang et al., 2005). The results also revealed that BPR, effective project management, companywide support, and organizational culture have a positive impact on the perceived benefits of ERP. This result confirmed the observations of previous studies (Cheng \& Wang, 2006; Zhang et al., 2005), and conform to Ram and Corkindale's (2014) conceptualization of CSFs by empirical proof that BPR, effective project management, company-wide support, and organizational culture are CSFs for ERP success in the post-implementation phase.

Surprisingly, top management support does not impact the perceived benefits of ERP. However, this result is in line with the findings of Norton, Coulson-Thomas, Coulson-Thomas, and Ashurst (2013), which suggested that top management involvement during the onward and upward phase of ERP II implementation has the potential to divert the ERP project from its planned track, especially if the main focus of top management is efficiency savings. However, this result differs from the findings of El Sawah et al. (2008), Dezdar and Ainin (2011a), and Soja (2006). There are two possible reasons for this result. First, the ERP users understated the role of top management support, as the ERP system is often developed and deployed by foreign software companies. Second, culture in Jordan accepts power distance and inequality. Thus, the convention is not only that top 
management executives have the right to withdraw themselves from ERP implementation details because they have more important obligations, responsibilities, and meetings to attend to, but also that the inclusion of reporting mechanisms to keep these executives informed about the progress of ERP implementation is considered more than sufficient.

According to Wang and Chen (2006), top executives are likely not to be actively involved in the day-to-day implementation process of ERP. A quote from Hawari and Heeks (2010) explains this phenomenon: "companies which implement ERP for the first time usually have an ERP project manager who belongs to the ERP Vendor." Furthermore, the results showed that the relative importance of CSFs in explaining variance in the perceived benefits of ERP was as follows: company-wide support, effective project management, BPR, and organizational culture. Overall, they were able to explain about $63.5 \%$ of the variance in ERP perceived benefits. This result expands prior studies that only highlighted the role of customization and organizational mechanisms (Chou and Chang, 2008) and ERP usage (Nwankpa, 2015) in achieving ERP benefits, but, unlike the current study, did not take into account the role of top management support, BPR, effective project management, company-wide support, and organizational culture in realizing expected ERP system benefits.

Further, although these previous studies apparently linked some internal and external factors to ERP benefits, they conflated ERP benefits as a latent variable, which blurred the explanatory power of CSFs on each type of expected benefit. Finally, there is a significant positive impact of vendor environment represented by vendor support on ERP perceived benefits. This result is in line with the results of Chou and Chang (2008), Maditinos et al. (2011), and Nwankpa (2015), who confirmed the existence of a positive relationship between vendor support and the immediate and overall benefits of ERP. However, this result contrasts with the findings of Zhu et al. (2010), who showed that vendor support was not essential to ERP success at the post-implementation stage in the retail industry.

\section{Limitations and Recommendations}

Based on the research results, we offer a set of recommendations to enhance the deployment and utilization of ERP among Jordanian organizations. The researchers hope that such recommendations will be given serious consideration so as to enhance the perceived benefits of the ERP system. Some of the recommendations are directed toward the scientific and research community and are aimed at enhancing the existing body of knowledge in general and relating specifically to the domain of this study.

The current study, like other cross-sectional studies, is not without limitations, and these can be addressed in future research. The research relies mainly on a questionnaire to collect relevant data, and this is a tool that is not free from bias. Future research could utilize other approach methods, such as interviews or focus groups, to understand fully the phenomena under investigation.

Although this study sheds light on factors influencing the perceived benefits of ERP, it does not investigate all factors that impact these benefits. Thus, future studies could extend the research model by adding other factors that may change the perceptions of the perceived benefits of ERP, such as IT self-efficacy, types of leadership, and the turbulence of the business environment. The current study also fails to find any impact for top management support on perceived benefits of ERP, which may be attributed to perceptual data. Therefore, future research could re-test and scrutinize the presumed impact by using objective data to measure perceived benefits. The current study also depends on one source of informant (users) without making clear distinctions between users. Future research could also create a taxonomy of ERP system users to deepen our understanding of why some users perceived more benefits than others. 
Future studies should also endeavor to employ various informants for each company, as this will produce more balanced, fair, and objective data. Further, the generalizability of the research findings is limited to the research sample and the results should be taken with caution. In order to increase the generalizability of the results, future research could apply the same model to other common types of ERP systems, such as SAP systems. Future studies could also enhance our understanding of when and why the overall expected benefits of ERP do or do not occur by investigating how CSFs influence immediate ERP benefits (Chou \& Chang, 2008; Gattiker \& Goodhue, 2005; Nwankpa, 2015). The current study provides guidelines not only for organizations that have already deployed ERP, but also for organizations that are intending to buy a new ERP system.

Business organizations in Jordan that use ERP should give more attention to combining company-wide support to ensure the success of the ERP system in delivering its perceived benefits. Business organizations that are considering buying a new ERP system or upgrading an existing one should be aware of the importance of obtaining ERP vendor support in order to gain more benefits. Business managers should place more emphasis on creating a culture that believes in the perceived benefits of ERP. They should also properly align internal and external organizational environments in order to utilize ERP systems successfully. Finally, business managers should measure perceived benefit levels frequently in order to gauge the impact of ERP on organizational performance.

\section{Conclusions}

As this study aims to understand how each CSF affects ERP benefits, it extends prior research by showing how the most cited CSFs in the literature affect each of the perceived benefits of ERP. The study helps to predict the influence of top management support, BPR, effective project management, organizational culture, and vendor support on the perceived benefits of ERP, such as IT infrastructure benefits, operational benefits, managerial benefits, strategic benefits, and organizational benefits. In fact, the current research makes the following main contributions:

1. It illustrates how each CSF influences the perceived benefits of ERP and recognizes those that have the greatest impact.

2. It confirms that BPR, effective project management, company-wide support, and organizational culture are the most important CSFs for ERP success in an SME setting.

3. It indicates that organizational environment plays a critical role in leveraging the expected benefits of ERP.

4. Unlike prior studies, it shows that top management support does not have any relationship with the perceived benefits of ERP in SMEs. This indicates that not all CSFs play a significant role in realizing ERP benefits in all ERP implementation phases.

5. It expands prior studies by showing the relative importance of CSFs in explaining the perceived benefits of ERP by ranking them as follows: company-wide support, effective project management, BPR, and organizational culture. This could be a road map for SMEs wishing to reap more ERP benefits during the post-implementation phase.

6. It confirms the existence of a positive relationship between vendor support and ERP benefits.

Finally, although this study builds on gaps in prior studies, it makes various contributions and has several limitations that are open trajectories for future researchers in developed and developing countries alike. 


\section{References}

Al-Mashari, M., Al-Mudimigh, A., \& Zairi, M. (2003). Enterprise resource planning: A taxonomy of critical factors. European Journal of Operational Research, 146(2), 352-364.

Bharathi, V., Vaidya, O., \& Parikh, S. (2012). Prioritizing and ranking critical success factors for ERP adoption in SMEs. AIMS International Journal of Management, 6(1), 23-40.

Cameron, K. S., \& Quinn, R. E. (2005). Diagnosing and changing organizational culture: Based on the competing values framework. John Wiley \& Sons.

Cheng, E. Y., \& Wang, Y. J. (2006). Business process reengineering and ERP systems benefits. Proceedings of the 11th Annual Conference of Asia Pacific Decision Sciences Institute, June 14-18, 201-213.

Chou, S. W., \& Chang, Y. C. (2008). The implementation factors that influence the ERP (enterprise resource planning) benefits. Decision Support Systems, 46(1), 149-157.

Churchill, G. A., Jr. (1979). A paradigm for developing better measures of marketing constructs. Journal of Marketing Research, 64-73.

Dezdar, S. (2010). Critical factors affecting ERP implementation success. University of Malaya, unpublished doctoral thesis.

Dezdar, S., \& Ainin, S. (2011a). Critical success factors for ERP implementation: insights from a MiddleEastern country. Middle-East Journal of Scientific Research, 10(6), 798-808.

Dezdar, S., \& Ainin, S. (2011b). Examining ERP implementation success from a project environment perspective. Business Process Management Journal, 17(6), 919-939.

Dezdar, S., \& Ainin, S. (2011c). The influence of organizational factors on successful ERP implementation. Management Decision, 49(6), 911-926.

El Sawah, S., Abd El Fattah Tharwat, A., \& Hassan Rasmy, M. (2008). A quantitative model to predict the Egyptian ERP implementation success index. Business Process Management Journal, 14(3), 288-306.

Esteves, J. (2009). A benefits realisation road-map framework for ERP usage in small and medium-sized enterprises. Journal of Enterprise Information Management, 22(1/2), 25-35.

Finney, S., \& Corbett, M. (2007). ERP implementation: A compilation and analysis of critical success factors. Business Process Management Journal, 13(3), 329-347.

Gable, G. G., Sedera, D., \& Chan, T. (2003). Enterprise systems success: A measurement model. Proceedings of the 24th International Conference on Information Systems, Association for Information Systems, Seattle, Washington, USA, 576-591.

Gattiker, T. F., \& Goodhue, D. L. (2005). What happens after ERP implementation: Understanding the impact of interdependence and differentiation on plant-level outcomes. MIS Quarterly, 29(3), 559-585.

Grabski, S. V., Leech, S. A., \& Schmidt, P. J. (2011). A review of ERP research: A future agenda for accounting information systems. Journal of Information Systems, 25(1), 37-78.

Hair, J. F., Black, W. C., Babin, B. J., Anderson, R. E., \& Tatham, R. L. (2006). Multivariate data analysis (Vol. 6). Upper Saddle River, NJ: Pearson Prentice Hall.

Hair, J. F., Hult, G. T. M., Ringle, C., \& Sarstedt, M. (2013). A primer on partial least squares structural equation modeling (PLS-SEM). Sage Publications.

Hammer, M. (1990). Reengineering work: Don’t automate, obliterate. Harvard Business Review, 68(4), 104-112.

Hawari, A. A., \& Heeks, R. (2010). Explaining ERP failure in a developing country: A Jordanian case study. Journal of Enterprise Information Management, 23(2), 135-160.

Holland, C. P., \& Light, B. (1999). A critical success factors model for ERP implementation. IEEE Software, 16(3), 30-36. 
Ifinedo, P. (2011). Examining the influences of external expertise and in-house computer/IT knowledge on ERP system success. Journal of Systems and Software, 84(12), 2065-2078.

Ifinedo, P., \& Nahar, N. (2006). Quality, impact and success of ERP systems: A study involving some firms in the Nordic-Baltic region. Journal of Information Technology Impact, 6(1), 19-46.

Jones, M. C., Cline, M., \& Ryan, S. (2006). Exploring knowledge sharing in ERP implementation: An organizational culture framework. Decision Support Systems, 41(2), 411-434.

Kamhawi, E. M. (2008). Enterprise resource-planning systems adoption in Bahrain: Motives, benefits, and barriers. Journal of Enterprise Information Management, 21(3), 310-334.

Ke, W., \& Wei, K. K. (2008). Organizational culture and leadership in ERP implementation. Decision Support Systems, 45(2), 208-218.

Law, C. C., \& Ngai, E. W. (2007). ERP systems adoption: An exploratory study of the organizational factors and impacts of ERP success. Information \& Management, 44(4), 418-432.

Liang, H., Saraf, N., Hu, Q., \& Xue, Y. (2007). Assimilation of enterprise systems: The effect of institutional pressures and the mediating role of top management. MIS Quarterly, 31(1), 59-87.

Madapusi, A., \& D'Souza, D. (2012). The influence of ERP system implementation on the operational performance of an organization. International Journal of Information Management, 32(1), 24-34.

Maditinos, D., Chatzoudes, D., \& Tsairidis, C. (2011). Factors affecting ERP system implementation effectiveness. Journal of Enterprise Information Management, 25(1), 60-78.

Markus, M. L., \& Tanis, C. (2000). The enterprise systems experience-from adoption to success. Framing the domains of IT research: Glimpsing the future through the past, 173, 207-173.

Moohebat, M. R., Jazi, M. D., \& Asemi, A. (2011). Evaluation of the ERP implementation at Esfahan Steel Company based on five critical success factors: A case study. International Journal of Business \& Management, 6(5), 236-246.

Murphy, K. E., \& Simon, S. J. (2002). Intangible benefits valuation in ERP projects. Information Systems Journal, 12(4), 301-320.

Nah, F. F. H., Islam, Z., \& Tan, M. (2008). Empirical assessment of factors influencing success of enterprise resource planning implementations. In Gordon, H. M. (Ed.), Selected Readings on Strategic Information Systems, (pp. 276-299). Hershey, PA: IGI Global.

Ngai, E. W., Law, C. C., \& Wat, F. K. (2008). Examining the critical success factors in the adoption of enterprise resource planning. Computers in Industry, 59(6), 548-564.

Norton, A. L., Coulson-Thomas, Y. M., Coulson-Thomas, C. J., \& Ashurst, C. (2013). Ensuring benefits realisation from ERP II: the CSF phasing model. Journal of Enterprise Information Management, 26(3), 218-234.

Noudoostbeni, A., Ismail, N. A., Jenatabadi, H. S., \& Yasin, N. M. (2010). An effective end-user knowledge concern training method in enterprise resource planning (ERP) based on critical factors (CFs) in Malaysian SMEs. International Journal of Business \& Management, 5(7), 63-76.

Nour, M. A., \& Mouakket, S. (2011). A classification framework of critical success factors for ERP systems implementation: A multi-stakeholder perspective. International Journal of Enterprise Information Systems, 7(1), 56-71.

Nwankpa, J. K. (2015). ERP system usage and benefit: A model of antecedents and outcomes. Computers in Human Behavior, 45, 335-344.

Patil, B., Narkhede, B., Mahajan, S., and Joshi, A. (2012). Performance evaluation of enterprise resource planning (ERP) systems in Indian manufacturing industries. International Journal of Research in Management and Technology, 2(1), 72-75.

Ram, J., \& Corkindale, D. (2014). How "critical" are the critical success factors (CSFs)? Examining the role of CSFs for ERP. Business Process Management Journal, 20(1), 151-174. 
Ramayah, T., Roy, M. H., Arokiasamy, S., Zbib, I., \& Ahmed, Z. U. (2007). Critical success factors for successful implementation of enterprise resource planning systems in manufacturing organizations. International Journal of Business Information Systems, 2(3), 276-297.

Ranganathan, C., \& Brown, C. V. (2006). ERP investments and the market value of firms: Toward an understanding of influential ERP project variables. Information Systems Research, 17(2), 145-161.

Razmi, J., Sangari, M.S., \& Ghodsi, R. (2009). Developing a practical framework for ERP readiness using fuzzy analytic network process. Advances in Engineering Software, 40(11), 1168-78.

Remus, U. (2007). Critical success factors for implementing enterprise portals: A comparison with ERP implementations. Business Process Management Journal, 13(4), 538-552.

Rugg, G., Eva, M., Mahmood, A., Rehman, N., Andrews, S., \& Davies, S. (2002). Eliciting information about organizational culture via laddering. Information Systems Journal, 12(3), 215-229.

Rugg, G., \& Krumbholz, M. (1999). Determining culture for effective ERP installation. $1^{\text {st }}$ International Workshop on Enterprise Management Resource and Planning Systems EMRPS, Venice, Italy, 135151.

Schniederjans, D., \& Yadav, S. (2013). Successful ERP implementation: An integrative model. Business Process Management Journal, 19(2), 364-398.

Sedera, D., Gable, G., \& Chan, T. (2003). Knowledge management for ERP success. Proceedings of the 7th PACIS, Adelaide, Australia.

Shang, S., \& Seddon, P. B. (2000). A comprehensive framework for classifying the benefits of ERP systems. Americas Conference on Information Systems, paper number1005-1014, Dallas, TX.

Shang, S., \& Seddon, P. B. (2002). Assessing and managing the benefits of enterprise systems: The business manager's perspective. Information Systems Journal, 12(4), 271-299.

Shao, Z., Feng, Y., \& Liu, L. (2012). The mediating effect of organizational culture and knowledge sharing on transformational leadership and enterprise resource planning systems success: An empirical study in China. Computers in Human Behavior, 28(6), 2400-2413.

Sheu, C., Chae, B., \& Yang, C. L. (2004). National differences and ERP implementation: Issues and challenges. Omega, 32(5), 361-371.

Soja, P. (2006). Success factors in ERP systems implementations: Lessons from practice. Journal of Enterprise Information Management, 19(6), 646-661.

Tsai, W. H., Shaw, M. J., Fan, Y. W., Liu, J. Y., Lee, K. C., \& Chen, H. C. (2011). An empirical investigation of the impacts of internal/external facilitators on the project success of ERP: A structural equation model. Decision Support Systems, 50(2), 480-490.

Umble, E. J., Haft, R. R., \& Umble, M. M. (2003). Enterprise resource planning: Implementation procedures and critical success factors. European Journal of Operational Research, 146(2), 241-257.

Wang, E. T., \& Chen, J. H. (2006). Effects of internal support and consultant quality on the consulting process and ERP system quality. Decision Support Systems, 42(2), 1029-1041.

Wang, E. T., Shih, S. P., Jiang, J. J., \& Klein, G. (2008). The consistency among facilitating factors and ERP implementation success: A holistic view of fit. Journal of Systems and Software, 81(9), 16091621.

Yu, C. S. (2005). Causes influencing the effectiveness of the post-implementation ERP system. Industrial Management \& Data Systems, 105(1), 115-132.

Yusuf, Y., Gunasekaran, A., \& Abthorpe, M. S. (2004). Enterprise information systems project implementation: A case study of ERP in Rolls-Royce. International Journal of Production Economics, 87(3), 251-266. 
Zhang, Z., Lee, M. K., Huang, P., Zhang, L., \& Huang, X. (2005). A framework of ERP systems implementation success in China: An empirical study. International Journal of Production Economics, 98(1), 56-80.

Zhu, Y., Li, Y., Wang, W., \& Chen, J. (2010). What leads to post-implementation success of ERP? An empirical study of the Chinese retail industry. International Journal of Information Management, $30(3), 265-276$.

\section{Appendix: Questionnaire items}

\begin{tabular}{|c|c|}
\hline \multirow[t]{2}{*}{ Top management support } & Top management is providing leadership for ERP Project implementation. \\
\hline & Top management is providing the necessary resources for ERP project. \\
\hline \multirow{3}{*}{$\begin{array}{l}\text { Business process reengi- } \\
\text { neering }\end{array}$} & Our company is capable for reengineering. \\
\hline & Our company is ready for change. \\
\hline & Our company is willing for reengineering. \\
\hline \multirow{4}{*}{$\begin{array}{l}\text { Effective project man- } \\
\text { agement }\end{array}$} & Our company having periodic project status meetings. \\
\hline & Our company having a realistic project time frame. \\
\hline & Our company having an effective project leader who is also a champion. \\
\hline & Our company having project team members who are stakeholders. \\
\hline \multirow[t]{5}{*}{ Company-wide support } & In our company, other users outside the teams support the ERP project. \\
\hline & In our company, users are enthusiastic about using ERP system. \\
\hline & Our functional department heads commit help in implementing ERP project. \\
\hline & Our Functional department heads are champions of the ERP project. \\
\hline & $\begin{array}{l}\text { Our functional department heads provide necessary resources to support } \\
\text { their subordinates. }\end{array}$ \\
\hline \multirow[t]{15}{*}{ Organizational culture } & $\begin{array}{l}\text { Our company is a very personal place. It is like an extended family. People } \\
\text { seem to share a lot of themselves. }\end{array}$ \\
\hline & $\begin{array}{l}\text { The leadership in our organization is generally considered to exemplify } \\
\text { mentoring, facilitating, or nurturing. }\end{array}$ \\
\hline & $\begin{array}{l}\text { The management style in our organization is characterized by teamwork, } \\
\text { consensus, and participation. }\end{array}$ \\
\hline & $\begin{array}{l}\text { The glue that holds our organization together is loyalty and mutual trust. } \\
\text { Commitment to this organization runs high. }\end{array}$ \\
\hline & $\begin{array}{l}\text { Our organization emphasizes human development. High trust, openness, and } \\
\text { participation persist. }\end{array}$ \\
\hline & $\begin{array}{l}\text { Our company defines success on the basis of the development of human } \\
\text { resources, teamwork, employee commitment, and concern for people. }\end{array}$ \\
\hline & $\begin{array}{l}\text { Our organization is a very dynamic and entrepreneurial place. People are } \\
\text { willing to stick their necks out and take risks. }\end{array}$ \\
\hline & $\begin{array}{l}\text { The leadership in our organization is generally considered to exemplify } \\
\text { entrepreneurship, innovation, or risk taking }\end{array}$ \\
\hline & $\begin{array}{l}\text { The management style in our organization is characterized by individual risk } \\
\text { taking, innovation, freedom, and uniqueness. }\end{array}$ \\
\hline & $\begin{array}{l}\text { The glue that holds our organization together is commitment to innovation } \\
\text { and development. There is an emphasis on being on the cutting edge. }\end{array}$ \\
\hline & $\begin{array}{l}\text { Our organization emphasizes acquiring new resources and creating new } \\
\text { challenges. Trying new things and prospecting for opportunities are valued. }\end{array}$ \\
\hline & $\begin{array}{l}\text { Our organization defines success on the basis of having the most unique or } \\
\text { newest products. It is a product leader and innovator. }\end{array}$ \\
\hline & $\begin{array}{l}\text { Our organization is very results oriented. A major concern is with getting the } \\
\text { job done. People are very competitive and achievement-oriented. }\end{array}$ \\
\hline & $\begin{array}{l}\text { The leadership in our organization is generally considered to exemplify a } \\
\text { no-nonsense, aggressive, results oriented focus. }\end{array}$ \\
\hline & $\begin{array}{l}\text { The management style in our organization is characterized by hard-driving } \\
\text { competitiveness, high demands, and achievement. }\end{array}$ \\
\hline
\end{tabular}




\begin{tabular}{|c|c|}
\hline & $\begin{array}{l}\text { The glue that holds our organization together is the emphasis on achieve- } \\
\text { ment and goal accomplishment. }\end{array}$ \\
\hline & $\begin{array}{l}\text { Our organization emphasizes competitive actions and achievement. Hitting } \\
\text { stretch targets and winning in the marketplace are dominant. }\end{array}$ \\
\hline & $\begin{array}{l}\text { Our organization defines success on the basis of winning in the marketplace } \\
\text { and outpacing the competition. Competitive market leadership is key. }\end{array}$ \\
\hline & $\begin{array}{l}\text { Our organization is a very controlled and structured place. Formal proce- } \\
\text { dures generally govern what people do. }\end{array}$ \\
\hline & $\begin{array}{l}\text { The leadership in our organization is generally considered to exemplify } \\
\text { coordinating, organizing, or smooth-running efficiency. }\end{array}$ \\
\hline & $\begin{array}{l}\text { The management style in our organization is characterized by security of } \\
\text { employment, conformity, predictability, and stability in relationships. }\end{array}$ \\
\hline & $\begin{array}{l}\text { The glue that holds our organization together is formal rules and policies. } \\
\text { Maintaining a smooth-running organization is important. }\end{array}$ \\
\hline & $\begin{array}{l}\text { Our organization emphasizes permanence and stability. Efficiency, control, } \\
\text { and smooth operations are important. }\end{array}$ \\
\hline & $\begin{array}{l}\text { Our organization defines success on the basis of efficiency. Dependable } \\
\text { delivery, smooth scheduling, and low-cost production are critical. }\end{array}$ \\
\hline \multirow[t]{3}{*}{ Vendor support } & $\begin{array}{l}\text { Our firm has qualified consultants who are knowledgeable on both enter- } \\
\text { prises' business processes and IT, including vendors' ERP systems. }\end{array}$ \\
\hline & Our ERP software vendor participates in implementation process. \\
\hline & Service response time of our software vendor is high. \\
\hline \multirow[t]{3}{*}{ IT infrastructure benefits } & $\begin{array}{l}\text { ERP implementation helps in building business flexibility for current and } \\
\text { future changes. }\end{array}$ \\
\hline & The implementation of ERP leads to IT cost reduction. \\
\hline & The implementation of ERP systems increases IT infrastructure capability. \\
\hline \multirow[t]{5}{*}{ Operational benefits } & The implementation of ERP systems leads to cycle time reduction. \\
\hline & The implementation of ERP systems leads to productivity improvements. \\
\hline & The implementation of ERP systems leads to quality improvements. \\
\hline & The implementation of ERP systems leads to cost reduction. \\
\hline & $\begin{array}{l}\text { The implementation of ERP systems leads to customer services improve- } \\
\text { ment. }\end{array}$ \\
\hline \multirow[t]{3}{*}{ Managerial benefits } & The implementation of ERP systems leads to better resource management. \\
\hline & The implementation of ERP systems leads to performance improvement. \\
\hline & $\begin{array}{l}\text { The implementation of ERP systems leads to improved decision making and } \\
\text { planning. }\end{array}$ \\
\hline \multirow[t]{6}{*}{ Strategic benefits } & The implementation of ERP systems helps in building external linkages. \\
\hline & The implementation of ERP systems supports business growth. \\
\hline & The implementation of ERP systems helps in building cost leadership. \\
\hline & The implementation of ERP systems supports business alliances. \\
\hline & $\begin{array}{l}\text { The implementation of ERP systems helps in generating product differentia- } \\
\text { tion. }\end{array}$ \\
\hline & The implementation of ERP systems helps in building business innovations. \\
\hline \multirow[t]{4}{*}{ Organizational benefits } & The implementation of ERP systems helps in changing work patterns. \\
\hline & The implementation of ERP systems helps in facilitating business learning. \\
\hline & The implementation of ERP systems leads to empowerment. \\
\hline & The implementation of ERP systems helps in building common visions. \\
\hline
\end{tabular}




\section{Biographies}

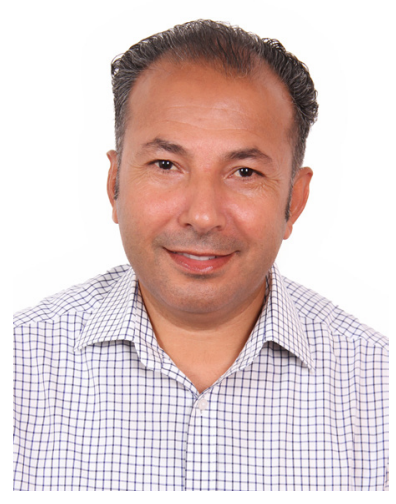

Soud Almahamid is an associate professor of e-business Systems and MIS at faculty of business administration, Middle East University, Jordan. Almahamid's work published in various local, regional, and international journals and conferences such as, Jordan Journal of Business Administration, Dirasat: Administrative Sciences, Journal of the Theoretical and Applied Information Technology, International Journal of Management, International Journal of Electronic governance, Interdisciplinary journal of Information, knowledge, and Management, International Journal of Business and Management, International Business Research, International Journal of Business Information Systems, Journal of King Saud University Administrative Sciences, Arab Journal of Administrative Sciences, etc. Almahamid's research interests include E-business Systems Usage; E-government System Acceptance and Usage; Knowledge Management and Sharing, Strategic Alignment; Information System Success; Ebusiness Systems Dependability; E-business Systems Quality; ERP system adoption; ERP system implementation, and ERP perceived benefits.

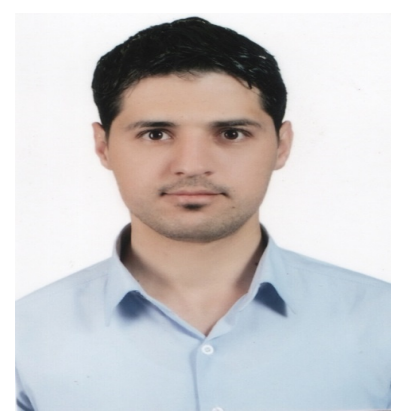

Omar Awsi is a Business Analyst working at Arabian Trade Co. Awsi holds a master degree in E-Business from Middle East University, Amman, Jordan. Awsi's research interests include ERP system benefits, factors that determine ERP perceived benefits. 